\title{
A comunicação, o rock e a cultura pop em André Forastieri
}

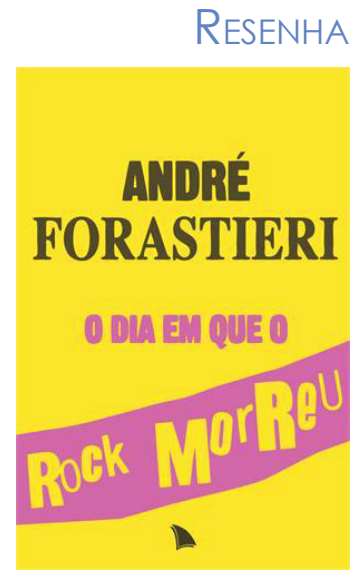

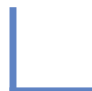

\section{Nilton F. de Carvalho}

Mestrando em Comunicação pela Universidade Municipal de São Caetano do Sul.

E-mail: niltonblog@gmail.com

A crítica musical possui engrenagem similar à composição. Se no campo da música a criação percorre o trajeto aberto pelas principais influências do artista, somadas a seu repertório cultural, a elaboração do texto crítico depende da maneira como o autor se relaciona com o tema, e o que pesquisou a respeito. No caso do livro $O$ dia em que o rock morreu, que reúne quarenta textos sobre rock, cultura pop e comunicação, assinados pelo jornalista André Forastieri, a segurança com a qual o articulista escreve sobre as temáticas propostas evita o surgimento de "achismos", garantindo ao leitor, no mínimo, um ponto de partida coerente, rumo à construção de uma opinião favorável ou contrária.

Os textos da coletânea conduzem o leitor por diferentes momentos da cronologia profissional do jornalista, que já elaborou resenhas e reportagens para o jornal Folha de $S$. Paulo, a extinta revista Bizz e atualmente mantém um blog ligado ao portal de notícias $R 7$. Dividida em quatro partes, a obra aborda temas ao redor do rock nos cenários nacional e internacional, traz discussões sobre artistas que repercutiram nos meios de comunicação tradicionais e propõe reflexões a respeito das inovações ocorridas nas indústrias da cultura e comunicação nos últimos anos.

Entende-se que o texto crítico, no campo do jornalismo, exige do autor amplo conhecimento sobre o assunto, percepção e sensibilidade que traduza pensamento em escrita. A principal diferença do texto opinativo para a reportagem é a ausência da obrigatoriedade da "isenção", a grande utopia das escolas de jornalismo. Com maior autonomia - dentro do campo da coerência, claro -, o jornalista pode tomar determinadas posições, defender ideias com bons argumentos e até usar moderados adjetivos - este último quesito localizado na linha tênue entre o exagero e o bom senso. Em Filosofia da nova 
música, por exemplo, o teórico da escola de Frankfurt Theodor Adorno argumenta, de maneira contundente, o motivo pelo qual prefere a música de Schoenberg a de Stravinsky. Outro exemplo é o pensamento que marca o período do Iluminismo, no momento em que Descartes afirma: "penso, logo existo", o ser humano pensante ganhou autonomia para construir a própria trajetória e, consequentemente, para optar por suas preferências de consumo, fato que se consolida após a ascensão da indústria cultural. Esse é o caminho percorrido por Forastieri em $O$ dia em que o rock morreu, trabalho que leva a crítica musical à forma literal de seu significado, expondo posições claras mas, ao mesmo tempo, permitindo que o leitor reflita, pense e tire suar próprias conclusões.

O livro se inicia com uma coletânea de textos sobre artistas de diferentes épocas - de Monkees a Michael Jackson -, que por algum motivo voltaram a ser notícia nos meios de comunicação. É o caso da cantora britânica Amy Winehouse, famosa por ter lançado o álbum Back to black, uma das obras mais comentadas da música pop recente, mas também conhecida pela carreira polêmica e trágica. O jornalista também tece elogios à revista britânica Uncut Magazine pela organização de uma coletânea musical que reúne roqueiros do cenário atual influenciados por Jimi Hendrix. Ao fazer menção ao guitarrista, o autor explica os porquês da importância de Hendrix na música - e a consequente relevância do CD comercializado junto com a revista.

O texto de Forastieri ganha aspectos literários nas três resenhas que encerram o bloco inicial de $O$ dia em que o rock morreu, nas quais o autor revela maior identificação com os artistas analisados. Nesse trecho, abre-se a possibilidade de compreender o jornalista também como fã, capaz de se emocionar e perceber certas obras com a sensibilidade de um ensaísta. Quando escreve sobre o grupo norte-americano The Cramps, por exemplo, o escritor deixa escapar narrativas autobiográficas que se mesclam ao momento no qual entrou em contato com o trabalho da banda pela primeira vez, humanizando um tema geralmente abordado apenas sob o olhar da isenção hermética, que cerceia o envolvimento dos profissionais da comunicação.

Ao adentrar as páginas que compõem a segunda parte de $O$ dia em que o rock morreu, o leitor logo se depara com textos de teor mais crítico, cujo conteúdo não poupa artistas, consumidores e profissionais da área de comunicação. À ideia de subir o tom soma-se o descontentamento do jornalista com os artistas do rock brasileiro atual. Em meio a um período de constantes mudanças, fluidez característica da sociedade pós-moderna, o autor parece narrar um processo de escassez das fontes criativas que por tempos abasteceram o campo das artes - e possivelmente da comunicação. Em texto irônico, e com certa amargura, Forastieri analisa os motivos que levaram o grupo de pop rock Restart a vencer tantos prêmios em um evento organizado pela MTV Brasil. Em outro momento, com a 
mesma euforia ao avesso, o jornalista descreve um Roberto Carlos decadente e pouco criativo nos especiais de fim de ano da Rede Globo. Resta então, sob os efeitos de tempos difíceis, lamentar também a morte do vocalista e guitarrista da banda punk Cólera, segundo o autor, enterrado sob os olhares de poucas pessoas, no cemitério da Vila Alpina, em São Paulo.

A seleção de artigos que dão continuidade à obra é introduzida por dois textos que discutem nomes do jornalismo cultural. Um deles sobre Paul Williams, idealizador do Crawdaddy!, primeiro magazine norte-americano especializado em rock. O outro narra o encerramento da versão impressa da revista Spin - que atualmente existe apenas no formato digital. A discussão proposta é aplicável aos dias de hoje, nos quais a sobrevivência de revistas e jornais impressos é constantemente posta em xeque. $\mathrm{O}$ autor, nos textos seguintes, ainda questiona os fãs de música acomodados com os recentes avanços do ambiente digital e sua gama considerável de discos para download pirata. Para o jornalista, de um lado está o amor do fã pelo artista (ou banda), e do outro a ausência de ética na hora comprar a obra original, considerando que o ato de baixar o disco ilegalmente, sem pagar, evita que o autor legítimo receba os valores referentes aos direitos autorais. Há também um texto sobre a saída da MTV da rede de transmissão de canais abertos (não pagos), no qual Forastieri aponta a ausência de uma gestão inovadora à frente do canal como um dos fatores determinantes para o seu fracasso. Entretanto, aponta que o fim da emissora abre espaço para o surgimento de novas possibilidades na internet, que permitem ao público criar canais de comunicação especializados em entretenimento e cultura pop, como as ferramentas oferecidas pela rede social YouTube.

O dia em que o rock morreu chega ao fim com uma seleção de textos dedicada à ascensão e à queda do lendário Kurt Cobain, vocalista e guitarrista da banda Nirvana, morto em 1994, após cometer suicídio. Forastieri narra um Cobain similar ao que foi imortalizado na literatura musical recente, desde a exposição midiática intensa, proporcionada pelo lançamento do álbum Nevermind (1991), passando pela sua visita ao Brasil, durante o festival Hollywood Rock, em 1993, ate as manchetes de jornais e revistas que percorreram o mundo no dia de sua morte. Ao final, o jornalista usa técnicas ficcionais para imaginar um Kurt Cobain contextualizado em nosso tempo, caso ainda estivesse vivo. Em um dos trechos polêmicos do livro, Forastieri abre, inclusive, a possibilidade de esgotamento da criatividade do músico, como se o álbum Nevermind, um marco do rock dos anos 1990, tivesse sido o último grande disco de rock.

A compreensível discordância do leitor com alguns pontos defendidos nas resenhas de $O$ dia em que o rock morreu não desqualifica a obra. Pelo contrário, estimula diferentes reflexões sobre os temas propostos, característica que agrega em si a essência 
do texto opinativo em jornalismo. Embora Forastieri apresente ideias controversas em determinados momentos do livro, suas argumentações também reúnem críticas similares ao pensamento de teóricos que veem na pós-modernidade um período de mudanças constantes na sociedade, que se refletem na comunicação, nas artes e nas relações sociais, o mesmo "impulso desconstrucionista" ao qual David Harvey se refere. Não à toa, a capa de $O$ dia em que o rock morreu faz clara menção à arte caótica que ilustra o álbum Never mind the bollocks (1977), do grupo britânico Sex Pistols, cujo termo "no future" era o slogan proposto em uma das canções.

FORASTIERI, André. O dia em que o rock morreu. Porto Alegre: Arquipélago Editorial, 2014. 